\title{
Effect of Heat Treatment Conditions on Micro Structure of Cast Iron
}

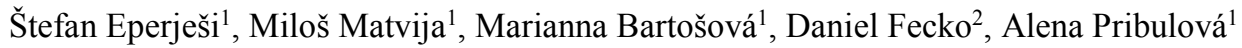 \\ ${ }^{1}$ Faculty of Metallurgy, Technical University of Košice. Letná 9, 04200 Košice. Slovakia. \\ E-mail: stefan.eperjesi.2@tuke.sk,milos.matvija@tuke.sk,marianna.bartosova@tuke.sk, alena.pribulova@tuke.sk \\ ${ }^{2}$ Zlievareň SEZ Krompachy, a.s. Hornádska 1, 05342 Krompachy. Slovakia. E-mail:daniel.fecko@zlievaren-sez.sk
}

Article deals with problematice of influencing mechanical properties - tensile strength and hardness - of grey cast iron by heat treatment - refinement. Refinement could be in special cases applied also for grey cast iron castings in order to achieve special parameters of hardness and tensile strength of parts for specific purposes. Hardening and tempering of casting sis commonly used for ductile cast iron, but in special cases could be applied also for grey cast iron castings. Refinement - hardening and tempering - was provided on samples from materiál EN GJL 150, EN GJL 200 and EN GJL 250. Afterwards, measured values of tensile strength, hardness and fractography of materiál in poured state and after tempering on temperatures 250,350 and $450^{\circ} \mathrm{C}$ after quenching from austenitization temperature $920^{\circ} \mathrm{C}$ were compared. Achieved results are formulated in the evaluation part of article.

Keywords: Refinement, Hardening, Tempering, Grey Cast Iron, Ductile Cast Iron

\section{References}

[1] SUCHÁNEK, D., DUŠÁK, K. (2011). The impact of the cast-iron semi-finished product hardness on the surface quality after the machining process. In: Manufacturing Technology, Vol.11, No.11, pp. 66-70. FPTM. Czech Republic.

[2] VAŠKO, A. (2013). Influence of heat treatment on the microstructure of synthetic nodular cast iron. In: Manufacturing Technology, Vol.13, No.1, pp. 115-119. FPTM. Czech Republic.

[3] GEDEONOVÁ, Z., JELČ, I. (2000). Metalurgia liatin. HF TU Košice, Košice.

[4] HASSE, S. (1996). Duktiles Gusseisen. Schiele\&Schön, Berlin.

[5] WOLTERS, D. B. (1996). Wärmebehandlung von Gusseisen mit Lamellen- oder Kugelgraphit. In: Konstruiren und Giessen, Vol. 21, No. 2, pp. 4-20. Zentrale für Gussverwendung. Düsseldorf.

[6] DORAZIL, E. (1985). Vysokopevná bainitická tvárna litina. ČSAV, Praha.

[7] BREZNIČAN, M., FABIAN, P., MEŠKO, J., DRBÚL, M. (2013). The Simulation of Influence of Quenching Temperature on Properties of Bearing Rings, Manufacturing Technology, Vol.13, No.1, pp.20-25. FPTM. Czech Republic.

[8] FABIAN, P. (2006). Selektívne tepelné spracovanie grafitických liatin - Habilitation paper. Žilinská Univerzita, Žilina. 